\title{
COOPERATIVES AND THE INCOME TAX
}

\section{ISRAEL PACKel $\dagger$.}

Landmarks in growing fields of law frequently receive only passing contemporary attention. A recent income tax decision of the Third Circuit Court of Appeals, Keystone Automobile Club Casualty Company v. Commissioner, ${ }^{1}$ may or may not become a landmark in the law of cooperatives, but its relationship to the timely subject of democracy certainly makes it of more than passing concern. The case presents very strikingly the democracy of true cooperatives. The court, notwithstanding a statutory tax exemption in favor of cooperatives, refused to free two alleged mutual insurance companies from an assessment of $\$ 167,331.06$ because of its conclusion that they were not mutuals or cooperatives in view of the absence of democratic ownership and control.

This is by no means the first time that a spot-light has been thrown upon the democratic aspects of cooperatives. The late Mr. Justice Brandeis had occasion long ago to say that the aim of cooperatives is "economic democracy on lines of liberty, equality and fraternity." 2 In fact, in conjunction with emphasis upon the present day importance of a clear conception of the meaning of democracy, the former Senator George Wharton Pepper has defined democracy in terms of a cooperative institution as follows:

"As I use the term 'democracy' it means a society in which the people who compose it are their own governors, much as the policy-holders in a mutual life insurance company are their own insurers." 3

Claude R. Wickard, the Secretary of Agriculture, has said:

"Ever so often a democracy has to make certain that it is still a democracy. This test is a simple one-do the people still rule? And ever so often, a cooperative has to make certain that it is still a cooperative. This test also is a simple one-do the members rule?" 4

†B.S. in Econ., 1929, LL.B., 1932, LL. M., I933, University of Pennsylvania; member of the Philadelphia Bar; author of THE LAW OF TAE ORGanization AND Operation of CoOperatives (I940); Utility Service to Cooperatives (I938) 86 U. of PA. L. REv. 370; and contributor to legal periodicals.

I. 4 C. C. H. I94I Fed. Tax Serv. $\mid 967 \mathrm{r}, 4 \mathrm{r}-2$ U. S. T. C. $\llbracket 967 \mathrm{I}$ (C. C. A. 3d, I94I). (1929).

2. Dissesting opinion in Frost v. Corporation Commission, 278 U. S. 5I5, 536

3. Pepper, Spiritual Values in Education and Democracy (I94I) 43 GEN. MAG. \& Hist. Chron. I37, I40.

4. (I94I) 2 COOP. Digest 25. 
Thus the aspect of the self-government of political democracy is not far removed from that of economic democracy.

Legislative policy in favor of the economic democracy of cooperatives is seen on many fronts. The courts in many situations have recognized the need for treating cooperatives differently from ordinary business enterprises. The writer has already presented a general outline of the background. ${ }^{5}$ Here, the attempt will be to make more recent and complete that part of the picture which pertains to the income tax status of cooperatives.

Preliminarily, it may be advantageous to set forth the problem concretely by way of illustration. One hundred persons agree to cooperate in the purchase of gasoline for their automobiles. For this purpose they incorporate as a cooperative, and the corporation acquires a gasoline station to serve the members. The members are charged the current market price for gasoline delivered to them. At the end of the tax year, the receipts of the corporation are $\$ 12,000$ and its expenditures $\$ 10,000$. Must the corporation pay income tax on the $\$ 2,000$ difference? How is the situation affected by any one of the following factors: (I) if before the end of the taxable year, the $\$ 2,000$ is distributed to the one hundred members in proportion to their purchases of gasoline; (2) if this is done after the taxable year has ended; (3) if the $\$ 2,000$ is not distributed but is used to pay a debt incurred in purchasing a gasoline station; (4) if the $\$ 2,000$ is simply carried to surplus; or (5) if the $\$ 2,000$ is carried to surplus and certificates of interest in surplus are distributed before the end of the taxable year to the one hundred members in proportion to their purchases? Assume that the following year the one hundred members are charged five-sixths of the market price, so that at the end of the tax year there are no excess receipts. Is this situation inherently different from any of the foregoing situations?

Two matters must be given entirely separate consideration. One is tax exemption and the other is tax applicability. The two must not be confused. One is a matter of legislative grace; the other involves, in the absence of constitutional questions, merely statutory construction. In result, a tax exemption to a cooperative is no different from a statutory construction that a tax statute is not applicable to the operaions of a cooperative ; in either case no tax becomes due. But as a practical matter the distinction is important. ${ }^{6}$ In the case of an exemption,

5. Packet, Cooperattves (1940) ar et seq.

6. In Huntley v. Southern Oregon Sales, IO2 F. (2d) 538 (C. C. A. 9th, I939) this distinction was made to allow a cooperative to sue within four years instead of two years in order to obtain a refund of income taxes from which it claimed exemption. 
it is fitting and proper that there be a matter of public policy to justify it. In the other case, no justification need be sought, because there is equality of treatment so far as the legisiature has seen fit to make the statute operative. Thus in the case of the income tax, an exemption to a charity needs, and has, a justification; but the non-liability of a business corporation which has had in the taxable year no profits but only losses requires no special justification.

In this country the income tax liability of cooperatives has received little analysis, although some attention has been given to it by the courts. Most of the opinions in which the issues have been discussed give a perfunctory treatment, but little direct damage seems to have been done, because the discussions almost invariably have been dicta which in no way affected the proper result. Yet, a tremendous amount of money seems to be involved in hosts of cases which never even reach the courts, but which are disposed of in reliance upon language in such opinions. For example, in 1936 , which appears to be the last year for which complete figures are available, 4,olo farmers' cooperatives in the United States paid to their patrons in proportion to their patronage the sum of $\$ 25,380,000 .^{7}$ It is impossible to determine how much tax was collected on that sum and on accumulations which were retained by. cooperatives as reserves or as surplus.

\section{The English "Appeasement"}

Adherents of the cooperative movement in England might well say that the appeasement policy of the late Mr. Chamberlain did not start at Munich. In his budget speech for $1932,{ }^{8}$ he referred to the "vigorous and growing protest" against the existing, so-called exemption to cooperatives. In his efforts to appease, he consulted privately with representatives of the cooperatives, for which he was subjected to criticism. ${ }^{9}$ Ultimately, his recommendation was adopted, so that under Section $3^{\mathrm{I}}$ of the Finance Act of $1933^{10}$ "any reference to profits or gains" in the income tax law is "deemed to include a reference to a profit or surplus arising from transactions of the company or society with its members," but patronage refunds are authorized "to be deducted as expenses."

Prior to I933, cooperatives in England were liable only for a tax on income from their assets. ${ }^{11}$ In that year for the first time, they

7. Farm Credit Administration, A Statistical Handbook of Farmers' CoOPERATIVES (I938) 6.

8. See Cooperative Societies and Income Tax (I932) I73 L. T. 326.

9. (1933) I75 L. T. 313, 3I4. In his attempt to smooth ruffed feeling, he took the position that the Government was neither denying nor attacking the principle of mutuality but was merely defining the area in which it was operative. Id. at 428 .

io. Chitty's Stats. (1933) 1386.

II. INCOME TAX ACT OF I9I8, \& 39 (4), ChItTy's Stats. (IgI8) 676. See Jones v. South-West Lancashire Coal Owners' Ass'n, [1927] A. C. 827; New York Life Ins. Co. v. Styles, I4 App. Cas. 381 (1889). 
became liable for a tax on those receipts from members which they chose to retain instead of returning to the members. At the time of the proposed change, it was criticized ${ }^{12}$ on the ground that it ". . . recommended that these societies should be treated on the lines of an ordinary trading company, because this would meet criticism, without, in fact, placing any greater financial liability on the societies." The reason for this conclusion was the obvious point that the tax could easily be eluded in various ways. Indeed, at that very time it was indicated that cooperatives could avoid the tax by reducing their prices or by declaring maximum patronage dividends. Surpluses, if necessary, could be created either by imposing special assessments for that purpose, or by agreements for the retention of patronage refunds as loans to the cooperative. ${ }^{13}$

The question in England is old, and the controversy has been heated. In 1922, it was pointed out that great opposition arose among ordinary business men who considered that the cooperatives were sailing under false colors in claiming that cooperative dealings were distinguishable from ordinary business dealings. ${ }^{14}$ In I933, the tax collector and business vievpoint was stated by Mr. Hore-Belisha, Financial Secretary to the Treasury. ${ }^{15} \mathrm{He}$ said, as a good tax collector, ${ }^{16}$ that there should be some limit to mutuality because otherwise the whole country might be covered by cooperatives and the government would receive no income tax. For business, he said, they would like to see "equality of sacrifice as regards the Revenue."

For the cooperatives it was countered that if additional taxes were necessary they should be levied, and to the extent that they were applicable to cooperatives they would be paid, but that it was unfair to extend an income tax solely to tax cooperatives for what in fact was not income. The objections of business organizations were met with the comment that "the grievance is due to the spread of the practice of co-operative trading, and that is outside questions of tax." 17

\section{The United States "Topsy"}

In contrast to the rather deliberate course pursued in England, the problem of the taxation of cooperatives in the United States has merely

I2. (1932) 73 L. J. 75.

13. (1933) I75 L. T. 314.

14. See Crichton, Co-operative Societies and Income Tax (1922) 38 LAW Q. REv. 48 , in which reference is made to the Royal Commission appointed in IgIg which presented majority and minority views.

I5. (1933) I75 L. T. 427.

16. "To the tax collector, all receipts are income." Union Trust Co. v. Commissioner, II5 F. (2d) 86, 87 (C. C. A. 3d, r940), cert. denied, 313 U. S. 700 (I94I).

I7. (I932) 73 L. J. 75. 
been permitted to grow. True, there may have been some battles for and against certain exemptions, ${ }^{18}$ but, in the main, the provisions concerning cooperatives in the revenue acts have been adopted and continued haphazardly, without real study and analysis. Thus, as will be shown later, there are at least fifteen different types of exemptions relating to various kinds of cooperatives, and each of these seems to bear little or no relationship to the other. Objections to certain aspects of an exemption have been modified in one of the water-tight compartments, whereas the same objection in another kind of exemption has been completely ignored. There has been no real attempt to correlate the same problems insofar as they affect different kinds of cooperatives.

In making comparisons to the situation in England, several differences must be kept in mind. In England, it has always been true, as was indicated approximately seventy-five years ago, ${ }^{19}$ that cooperatives made it a practice to deal with the public, whereas in this country the tendency of cooperatives has been to prohibit, or to limit the amount of, dealings with non-members. In England, probably because of an early criticism, ${ }^{20}$ the practice of having a host of cooperative statutes, one for each functional type of cooperative, is much more limited than in this country, where in a single jurisdiction can be found a great number of acts for the incorporation of different kinds of cooperatives. A final distinction to be noted is that in England an income tax can be made applicable to non-income receipts without constitutional objection, whereas in this country income taxes may raise questions as to the limitations of the Constitution of the United States.

The Sixteenth Amendment empowered Congress "to lay and collect taxes on income, from whatever source derived, without apportionment among the several States, and without regard to any census or enumeration." In Farmers' Union Cooperative Co. v. Commissioner ${ }^{21}$ the Eighth Circuit Court of Appeals considered the contention on behalf of a cooperative that its receipts were not "income" within the meaning of the Sixteenth Amendment. It appears to be the only case on the subject. ${ }^{22}$ The cooperative argued that its activity differed from ordinary corporate economic practice because the distribution of

18. See note 55 infra.

I9. RICHTER, COOperative Stores (1867) c. 4.

20. Brabrook, The Cooperative Societies Act of $187 I$ (187x)' 32 LAW MAG. \& REv. (3d Series) I.

21. 90 F. (2d) 488 (C. C. A. 8 th, 1937).

22. In Penn Mutual Life Insurance Co. v. Lederer, 252 U. S. 523 (1920) it was urged unsuccessfully that the Sixteenth Amendment should lead the Court to construe the early legislation there involved in such a way that the receipts of a mutual insurance company should not be considered the equivalent of gross income. The Court did not discuss, however, any question of constitutionality. Subsequently a new system of taxation of life insurance companies was adopted, under which premiums were excluded from gross income and taxes were imposed upon interest, dividends and rents, less specified deductions. See National Life Ins. Co. v. United States, 277 U. S. 508 (I927). 
benefits is in proportion to individual dealings rather than in proportion to capital investment. The court said: "This argument would acquire force and would require examination here if such were the situation of petitioner." The court held, however, that it was not necessary to consider this serious question, because benefits did not pass according to patronage in that dividends up to eight per cent. were payable on stock and a substantial amount of business was done with non-members who were treated differently from members.

Thus, undecided today is this important question of whether receipts from members of a cooperative which conducts its affairs on a truly cooperative basis constitute income within the meaning of the Sixteenth Amendment. Counsel for cooperatives will no doubt argue that receipts from members are not economic gain but mere advances to the cooperative to meet expenses and in some cases to accumulate necessary reserves or surplus; whereas, the tax collector will argue that receipts are in fact, if not in theory, for the furnishing of economic services. It is to be noted that the undecided question relates to receipts from the members of the cooperative. It does not relate to other receipts. For example, if part of the receipts are used for investment purposes, then interest, dividends or capital gains on those investments are clearly taxable income. As will be noted subsequently, however, Congress has seen fit to exempt such income for certain kinds of cooperatives.

The absence of authority on the constitutional problem does not mean that there has been little litigation with regard to the liability of cooperatives for income taxes. The host of cases arising before the courts and the Board of Tax Appeals have been decided on the basis of the statutory provisions and the regulations. The constitutional question, apparently, has not been involved or possibly in some cases has been overlooked.

\section{Uncoordinated Tax Legislation as to Cooperatives}

A picture of the chaotic condition of the income taxation of cooperatives can be best presented by a reference to all the pertinent provisions of the Internal Revenue Code. The picture could be made more complicated by a reference to the many rules, regulations, and administrative rulings and decisions. For purposes of this article, however, it seems best to avoid such references. Income taxes are levied in relationship to "net income" which in Section $2 \mathrm{I}$ is defined as "gross income computed under Section 22, less the deductions allowed by Section 23." "Gross income" under Section 22

"includes gains, profits, and income derived from salaries, wages, or compensation for personal service . . ., of whatever kind and 
in whatever form paid, or from . . . trades, businesses, commerce, or sales, or dealings in property . . . growing out of the ownership or use of or interest in such property; also from interest, rent, dividends, securities, or the transaction of any business carried on for gain or profit, or gains or profits and income derived from any source whatever . . ."

and the only exclusion applicable to a cooperative is "to the extent provided in section II6. . . . Receipts of shipowners' mutual protection and indemnity associations." Section II6 (g) provides that the following shall not be included in gross income:

"The receipts of shipowners' mutual protection and indemnity associations not organized for profit, and no part of the net earnings of which inures to the benefit of any private shareholder; but such corporations shall be subject as other persons to the tax upon their net income from interest, dividends, and rents."

In lieu of the usual income taxes, a special classification is made in Supplement $G$ for insurance companies and in Supplement $Q$ for mutual investment companies. Supplement $G$ deals with three kinds of insurance companies: (I) life insurance companies; (2) insurance companies other than life or mutual; and (3) mutual insurance companies other than life. Section 20I of Supplement $G$ provides that "'life insurance company' means an insurance company engaged in the business of issuing life insurance and annuity contracts. . ." It might be contended that this definition does not include a mutual life insurance company, because a cooperative does not engage in business. That contention, however, loses its force, because Supplement G on its face appears to be all-inclusive. ${ }^{23}$ Section 202 defines "gross income" of insurance companies as "the gross amount of income received during the taxable year from interest, dividends and rents." Thus it excludes as part of income the premiums receievd from policyholders. In contrast, is Section 207 which provides that: "Mutual marine insurance companies shall include in gross income the gross premiums collected and received by them less amounts paid for reinsurance." The section further provides that mutual insurance companies other than life may deduct in addition to ordinary deductions:

"(A) the net addition required by law to be made within the taxable year to reserve funds. . .

(B) the sums other than dividends paid within the taxable year on policy and annuity contracts."

It then provides as an additional deduction for mutual marine insurance companies "amounts repaid to policyholders on account of premiums previously paid by them, and interest paid upon such amounts between the ascertainment and the payment thereof"; and as an addi-

23. Penn Mutual Life Insurance Co. v. Lederer, 252 U. S. 523 (Ig20). 
tional deduction for mutual insurance companies (other than life and marine) which require members to make premium deposits to provide for losses and expenses, "the amount of premium deposits returned to their policyholders and the amount of premium deposits retained for the payment of losses, expenses and reinsurance reserves."

Supplement $Q$ imposes a special income tax on so-called mutual investment companies which. in Section $36 \mathrm{I}$ are defined so as to mean "any domestic corporation . . . other than a personal holding company .. ." which complies with certain requirements such as "an amount not less than 90 per centum of its net income is distributed to its shareholders as taxable dividends during the taxable year; and . . . its shareholders are, upon reasonable notice, entitled to redemption of their stock for their proportionate interest in the corporation's properties, or the cash equivalent thereof less a discount not in excess of 3 per centum thereof".

\section{VARIETy In Statutory Exemptions}

In contrast to the provisions mentioned above as to non-taxability, as to computation of net income and as to special taxation of designated types of cooperatives, are the provisions for exemption. Section IOI exempts entirely from any obligation to pay income tax the following:

"(I) Labor, agricultural or horticultural organizations;

(2) Mutual savings banks not having a capital stock represented by shares; . . .

(4) Domestic building and loan associations substantially all the business of which is confined to making loans to members; and cooperative banks without capital stock organized and operated for mutual purposes and without profit;

(5) Cemetery companies owned and operated exclusively for the benefit of their members or which are not operated for profit

(7) Business leagues, chambers of commerce, real estate boards or boards of trade . . . profit . . .

(8) Civic leagues or organizations not organized for

(9) Clubs organized and operated exclusively for pleasure, recreation and other nonprofitable purposes, no part of, the net earnings of which inures to the benefit of any private shareholder;

(IO) Benevolent life insurance associations of a purely local character, mutual ditch or irrigation companies, mutual or cooperative telephone companies, or like organizations; but only if 85 per centum or more of the income consists of amounts collected from members for the sole purpose of meeting losses and expenses;

(II) Farmers' or other mutual hail, cyclone, casualty or fire insurance companies or associations . . . the income of which is used or held for the purpose of paying losses or expenses; 
(12) Farmers', fruit growers', or like associations organized and operated on a cooperative basis (a) for the purpose of marketing . . . and turning back . . . the [net] proceeds of sales ... or (b) for the purpose of purchasing of supplies and equipment . . . at actual cost, plus necessary expenses. Exemption shall not be denied any such association because it has capital stock, if the dividend rate of such stock is fixed . . . and if substantially all such stock . . . is owned by producers who market their products or purchase their supplies and equipment through the association; nor shall exemptions be denied any such association because there is accumulated and maintained by it a reserve required by state law or a reasonable reserve for any necessary purpose. . .

(I3) Corporations organized by an association exempt under the provisions of paragraph (I2), or members thereof, for the purpose of financing the ordinary crop operations of such members or other producers, and operated in conjunction with such association ...

(I4) Corporations organized for the exclusive purpose of holding title to property, collecting income therefrom, and turning over the entire amount thereof, less expenses, to an organization which is exempt . . .

(I6) Voluntary employees' beneficiary associations . . . if . . 85 per centum or more of the income consists of amounts collected from members . . .

(I7) Teachers' retirement fund associations of a purely local character

(I9) Voluntary employees' beneficiary associations . . . if . admission to membership in such association is limited to individuals who are officers or employees of the United States Government ..."

The cold picture presented by this statutory analysis of the exemptions may be given some life by discussing the way in which the provisions have fared in the courts. It would seem most convenient to do this by treating separately the various types of cooperatives. No one classification of cooperatives can be made to meet everyone's satisfaction but the ensuing division, heretofore made by the writer, ${ }^{24}$ seems to be satisfactory for most practical purposes.

Consumers' Cooperatives. There is no general exemption for consumers' cooperatives. ${ }^{25}$ It has been contended unsuccessfully that the twelfth exemption, to 'farmers', fruit growers', or like associations organized and operated on a cooperative basis . . .", is applicable to consumers' cooperatives. ${ }^{26}$ The courts have held that, because of the

24. PaCkei, COOPERATIVes (1940) get seq. $1940)$.

25. Cooperative Oil Ass'n, Inc. v. Commissioner, rr5 F. (2d) 666 (C. C. A. gth,

26. National Outdoor Advertising Bureau, Inc. v. Commissioner, 89 F. (2d) 878, 879 (C. C. A. 2d, I937) ; Sunset Scavenger Co., Inc. v. Commissioner, 84 F. (2d) 453, 
doctrine of ejusdem generis, the exemption must be confined to agricultural organizations like farmers' or fruit growers' associations.

Certain specific types of consumers' cooperatives, however, are exempted. Thus in the tenth exemption are included certain ". . . mutual ditch or irrigation companies, mutual or cooperative telephone companies, or like organizations . . .". A court may take the position that "like organizations" refers to other utility cooperatives such as rural electrification cooperatives. The draftsmanship of the provision, however, is far from satisfactory, because preceding the quoted language is the phrase "benevolent life insurance associations of a purely local character" which manifestly is outside the scope of utility cooperatives.

Whether a consumers' cooperative operating as a buying club comes within the ninth exemption to "clubs organized and operated exclusively for pleasure, recreation and other nonprofitable purposes . . . ", apparently, is undecided by any court. Although the word "nonprofitable" by itsel $\mathrm{m}$ might be used to describe the operations of a cooperative, ${ }^{27}$ that construction becomes difficult where the word is used in conjunction with "pleasure" and "recreation". ${ }^{28}$

The courts have had the occasion to consider the exemption status of housing cooperatives, a form of consumers' cooperative. In Garden Homes Company v. Commissioner ${ }^{29}$ exemption was claimed by such an organization as a (I) building and loan association, (2) consumers' cooperative, (3) municipal agency or (4) civic organization. The cooperative was denied the exemption on the first three grounds, but it was held to be exempt on the fourth ground. It should be noted, however, that in that case the City of Milwaukee had a real interest in the enterprise. In the more recent case of Amalgamated Housing Cor-

455 (C. C. A. 9th, I936); Garden Homes Co. v. Commissioner, 64 F. (2d) 593, 596 (C. C. A. 7 th, I933). In the first case the court stated that it need not consider whether the exemption without such a limitation would be discriminatory.

27. See PACKEL, CoOperatives (1940) 2I.

28. Cf. Amalgamated Housing Corp., 37 B. T. A. 8I7 (I938), aff'd, I08 F. (2d) roro (C. C. A. 2d, 1940) ("nonprofit" used in conjunction with "promotion of social welfare") ; Stanford University Bookstore v. Commissioner, 83 F. (2d) 710 (App. D. C. 1936) '(bookstore paying patronage refunds claimed to be operated for educational and non-profitable purposes). In Jockey Club v. Commissioner, $76 \mathrm{~F}$. (2d) 597, 598 (C. C. A. 2d, 1935) a jockey club was held non-exempt since mere proof that gross income other than dues was less than expenses did not show that transactions with nonmembers were not a source of income inuring to members.

29. 64 F. (2d) 593 (C. C. A. 7 th, I933). One reason given for the conclusion was that the corporate entity must be disregarded. In Wood v. Rasquin, 2I F. Supp. 2II (E. D. N. Y. I937), aff'd, 97 F. (2d) 1023 (C. C. A. 2d, 1938) the court refused to disregard the corporate entity so as to permit a member of the housing cooperative to deduct in his income tax return his portion of the mortgage interest and taxes paid by the cooperative. In Burr Creamery Corporation v. Commissioner, 62 F. (2d) 407 (C. C. A. 9th, I932), cert denied, 289 U. S. 730 (I933) the court took the position that it should not disregard the separate corporate entity of a wholly owned subsidiary of an exempt cooperative. 
poration v. Commissioner, ${ }^{30}$ a limited dividend housing cooperative was held to be non-exempt and the contention that it was a civic organization was rejected.

Marketing Cooperatives. In view of the tremendous growth of the marketing cooperative movement throughout the country, it is expectable that their tax exemption would present many cases raising questions of statutory construction. In almost all the cases, the problems have arisen because of dealings with non-members. The twelfth exemption requires "turning back" to members or other producers "the proceeds of sales, less the necessary marketing expenses."

Under this language the courts have established very clearly that there must be equality of treatment for non-members, or the exemption will be lost. Thus cooperatives are deprived of the exemption if patronage refunds are payable to members but not to non-members, ${ }^{31}$ or if only partial refunds are made to non-members. ${ }^{32}$ The same conclusion has been reached where patronage refunds were credited to nonmembers but only for accumulation to pay for a share of stock. ${ }^{33}$ In the latter situation it was held that it is not equality of treatment to require a non-member to become a member.

Not only must there be equality of treatment as to patronage refunds but also as to reserves or other accumulations. If the cooperative, instead of making patronage refunds, uses its excess receipts to increase its plant and equipment which "inure ultimately to the benefit of members to the exclusion of non-members" the exemption is lost. ${ }^{34}$ This is true even though the cooperative proves that its reserve or surplus was reasonable and necessary. ${ }^{35}$ Where receipts go to reserves or surplus, the necessary equality of treatment can be had by a protective recognition of non-members in surplus, ${ }^{36}$ or possibly by an effective provision that no part of the surplus or reserve should inure to the benefit of any member or individual. ${ }^{37}$

30. 37 B. T. A. 817 ( 1938 ), aff'd without opinion, Amalgamated Housing Corp. v. Commissioner, 108 F. (2d) roro. (C. C. A. 2d, 1940).

3I. Farmers' Union Co-operative Co. v. Commissioner, 90 F. (2d) 488 (C. C. A. 8th, I937) ; Fruit Growers' Supply Co. v. Commissioner, 56 F. (2d) 90 (C. C. A. 9th, 1932) ; Farmers' Co-op. Co. v. United States, 23 F. Supp. I23 (Ct. Cl. I938) ; Farmers' Union Co-op. Supply Co. v. United States, 23 F. Supp. 128 (Ct. Cl. I938).

32. Riverdale Co-op. Creamery Ass'n v. Commissioner, 48 F. (2d) 7II (C. C. A. 9th, I93I). I938).

33. Farmers' Union Co-op. Supply Co. v. United States, 25 F. Supp. 93 (Ct. Cl.

34. Fertile Coop. Dairy Ass'n v. Huston, 33 F. Supp. 712 (N. D. Iowa, I940), $a f{ }^{\prime} d$, Irg F. (2d) 274 (C. C. A. 8th, I94I) ; cf. Burr Creamery Corp. v. Commissioner, 62 F. (2d) 407 (C. C. A. 9 th, 1932).

35. Fertile Coop: Dairy Ass'n v. Huston, rrg F. (2d) 274 (C. C. A. 8th, r94r).

36. Id. at 277; of. Midland Cooperative Wholesale, 44 B. T. A. 824 (194I).

37. This might be accomplished by a charter provision that reserves and surplus upon liquidation should go to some charitable or public purpose. 
Business Purchasing Cooperatives. Ordinary business purchasing cooperatives are not exempt under the statute, ${ }^{38}$ but this is not true of farmers' purchasing cooperatives which come within the twelfth exemption by being organized and operated "for the purpose of purchasing of supplies and equipment . . at actual cost, plus necessary expenses." 39 Non-agricultural purchasing cooperatives have sought exemption on different grounds but have not met with success. Thus a printing cooperative ${ }^{40}$ and credit agency cooperatives ${ }^{41}$ have, unsuccessfully contended that they were exempt as business leagues under the seventh exemption.

Workers Productive Societies. An organization of workers who pool resources in order to operate their own plant or productive enterprise is unusual in this country, and apparently no such organization has been involved in income tax litigation. It might be contended that they come within the first exemption to "labor . . . organizations". The Board of Tax Appeals, however, has stated that: "The fact that its membership happens to consist mainly of laborers is not determinative." ${ }^{42}$ In two cases, one involving advertising agents ${ }^{43}$ and the other garbage collectors, ${ }^{44}$ cooperative corporations organized by them in conjunction with the furnishing of their services were held not to be within the twelfth exemption to 'farmers', fruit growers' or like associations organized and operated on a cooperative basis . .."

Financial Cooperatives. Included in the foregoing list of exemptions are five kinds of financial institutions, mutual savings banks, building and loan associations, ${ }^{45}$ cooperative banks, crop financing corporations and teachers' retirement fund associations. In $A-C$ Investment Ass'n v. Commissioner ${ }^{40}$ it was held that an unincorporated employees' association which received deposits from members and loaned money on real estate bonds and mortgages was a "mutual sav194I).

38. Bakers' Mutual Coop. Ass'n v. Commissioner, iı7 F. (2d) 27 (C. C. A. 3d,

39. The agricultural purchasing cooperative will of course be denied exemption if non-members are not given equality of treatment. See cases cited notes 3I-35 supra.

40. Uniform Printing \& Supply Co. v. Commissioner, 33 F. (2d) 445 (C. C. A. 7th, 1929), cert. denied, 280 U. S. 591 (I929).

4I. Retailers Credit Ass'n v. Commissioner, 90 F. (2d) 47 (C. C. A. 9th, I937); Northwestern Jobbers' Credit Bureau v. Commissioner, 37 F. (2d) 880 (C. C. A. 8th, I930); Durham Merchants' Ass'n v. United States, 34 F. Supp. 7 I (M. D. N. C. I940). But cf. Crooks v. Kansas City Hay Dealers' Ass'n, 37 F. (2d) 83 (C. C. A. 8th, 1929). 42. Workingmen's Cooperative Association, 3 B. T. A. 1352, 1354 (1926). But cf. Portland Co-operative Labor Temple Ass'n, 39 B. T. A. 450 (I939).

(C. 43. National Outdoor Advertising Bureau, Inc. v. Commissioner, 89 F. (2d) 878 I936)

44. Sunset Scavenger Co., Inc. v. Commissioner, 84 F. (2d) 453 (C. C. A. 9th, 45. Building and loan associations are entitled to the exemption even if some dealings are had with non-members. $C f$. United States v. Cambridge Loan \& Building Co., 278 U. S. 55 (1928).

46. 68 F. (2d) 386 (App. D. C. 1933). 
ings bank" within the second exemption. It was clearly a mutual organization. In this country there are many large savings banks without capital stock which are sometimes referred to as mutual savings banks, although they are not owned and controlled by the depositors. The question of whether they are properly entitled to exemption under the language of the statute apparently has not received judicial scrutiny.

Insurance Cooperatives. The Keystone Automobile Club case, ${ }^{47}$ referred to at the outset of this article, denied exemptions to two insurance companies which lacked mutuality in the sense that the companies were not democratically owned and controlled. In that case the two insurance companies were wholly owned subsidiaries of the Keystone Automobile Club. The directors of the insurance companies were elected by a proxy vote cast by the directors of the Club. The Club directors were elected by members of the Club, many of whom were not policyholders. Policyholders who were not members of the Club had no right to vote. The court said:

"Counsel for petitioners contend that 'the primary and fundamental characteristic of a mutual insurance company is that it be organized and operated exclusively for the purpose of furnishing insurance at cost to its policyholders.' This ignores an equally fundamental characteristic of mutual or cooperative organizations -democratic ownership and control." 48

Of similar import is the following statement in Ohio Farmers Indemnity Co.v. Commissioner:

"A mutual company is one in which the distinguishing feature is the mutuality of cooperation of the members united for that purpose, each taking a proportionate part in the management of its affairs and being at once insurer and insured, participating alike in its profits and losses, all its members being policyholders." 48

The significance of control of such organizations is apparent from the facts in Equitable Life Assurance Society v. Browen ${ }^{50}$ which reveal that to obtain majority control of an alleged mutual insurance company there was paid for shares with a par value of $\$ 50,200$, on which semi-annual dividends could not exceed $3 \frac{\mathrm{T}}{2}$ per cent., the sum of $\$ 2,500,000$. The shares were later sold for $\$ 3,000,000$ and still later for $\$ 4,000,000 .^{51}$

In Baltimore Equitable Society $v$. United States 52 the court held that the doing of Io per cent. of its business with non-members, de-

47. 4 C. C. H. I94I Fed. Tax Serv. $\int 967 \mathrm{I}, 4 \mathrm{I}-2$ U. S. T. C. $\llbracket 967$ I (C. C. A. 3d, I94I).

48. Ibid.

49. 108 F. (2d) 665,667 (C. C. A. 6th, 1940).

50. 213 U. S. 25, 3I (1909). 2d, I9I7).

5I. Royal Trust Co. v. Equitable Life Assur. Society, 247 Fed. 437, 442 (C. C. A.

52. 3 F. Supp. 427 (Ct. Cl., I933), cert. denied, 290 U. S. 662 (I933). 
prived an insurance company of an exemption as a mutual insurance company. ${ }^{53}$ In MacLaughlin v. Philadelphia Contributionship ${ }^{54}$ an admittedly mutual company was denied exemption because its purpose was not only insurance but also investment. ${ }^{\mathbf{5 5}}$

Labor Unions. Labor unions clearly come within the first exemption to "labor, agricultural, or horticultural organizations" which expression, it has been said, "bespeaks a liberal construction to embrace the common acceptation of the term, including labor unions and councils and the groups which are ordinarily organized to protect and promote the interests of labor." 56

Trade Associations. By definition a trade association does not engage in the activities normally carried out by its individual members. Accordingly, a trade association of investment brokers was not held exempt as a business league where it performed services which the individual members performed. ${ }^{57}$ Likewise, an association of insurance companies to improve uniformity and better standards loses its exemption as a business league when it carries out a program to do printing for its members..$^{58}$ Reference has already been made to a similar rule with regard to an agency of business men which engages in credit or collection work. ${ }^{69}$ A true trade association, however, seems to come within the seventh exemption to "business leagues, chambers of commerce, real estate boards or boards of trade."

Self Help Cooperatives. The limitation of self help cooperatives to use in conjunction with the administration of relief or charitable activities probably brings them within the eighth exemption to "civic leagues or organizations not organized for profit."

\section{Taxability of Receipts Distributed as Patronage Refunds}

The conclusion that a cooperative is not exempt from income tax still leaves open the important question of whether its receipts consti-

53. This conclusion was even more obvious in Driscoll v. Washington County Fire Ins. Co., IIo F. (2d) 485 (C. C. A. 3d, 1940), where a general business was done with non-members. Cf. Trinidad v. Sagrada Orden, 263 U. S. 578 (I924), where an exempt religious organization incidentally engaged in transactions in wine and chocolate with its "own organization and agencies" which the Court said was not trading in a proper sense because the dealings were not with the public or in competition with others.

54. 73 F. (2d) 582 (C. C. A. 3d, 1934), cert. denied, 294 U. S. 718 (1935).

55. See Penn Mutual L.ife Ins. Co. v. Lederer, 252 U. S. 523, 534 (I920), where the footnote comment made is: "The alleged unwisdom and injustice of taxing mutual life insurance companies while mutual savings banks were exempted had been strongly pressed upon Congress."

56. Portland Coop Labor Temple Ass'n, 39 B. T. A. 450, 455 (I939). 1938 ).

57. Northwestern Municipal Ass'n v. United States, 99 F. (2d) 460 (C. C. A. 8th,

58. Uniform Printing \& Supply Co. v. Commissioner, 33 F. (2d) 445 (C. C. A. 7th, I929), cert. denied, 280 U. S. 591 (r929).

59. See note 41 supra. 
tute taxable income within the meaning of the Internal Revenue Code. This is well illustrated by two separate decisions involving a cooperative, organized by 250 insurance companies, which, among other things, did the printing for the insurance company members. In the earlier case the claim of the cooperative to an exemption was fought unsuccessfully up to the Supreme Court of the United States. ${ }^{60}$ In the later case, the cooperative was successful in its contention that excess receipts amounting to $\$ 128,943.46$ which were refunded to members in proportion to patronage did not constitute taxable income. ${ }^{61}$ The court did not reach this conclusion upon the ground that the cooperative was a nonprofit organization. In fact, the court took the position that the "taxpayer is not a nonprofit corporation in a legal sense. It is subject to a tax upon the profits by it made. Nevertheless, net profits in its case must depend upon the facts." 82 The court concluded that the patronage refund was deductible as if it were a discount or a rebate made to customers.

The non-taxability of receipts from members of cooperatives which are distributed as patronage refunds is well settled. ${ }^{\text {B3 }}$ In a recent decision, however, a court went out of its way to state that this "is a question upon which we express no opinion." ${ }^{44}$ The court apparently had in mind that there was no specific statutory provision referring to such a deduction. It is essential, therefore, to clarify the basis upon which the income tax is not applicable to such receipts.

A fundamental principle applicable to all cooperatives is the avoidance in the organization of entrepreneur profit. Patronage refunds, therefore, are not to be considered as a division of the profits. They are rather a return of the overcharge. Indeed, in France patronage refunds are called "trop-percu". Thus, the very nature of the enterprise makes it implicit in all dealings with patrons that the excess of receipts will be returned in proportion to patronage. Of course, if the enterprise is not organized as a cooperative, the return of excess receipts in the form of patronage refunds is not implicit, and such sums are taxable if their payment is directed by way of resolution adopted after

60. Uniform Printing \& Supply Co. v. Commissioner, 33 F. (2d) 445 (C. C. A. 7th, I929), cert. denied, 280 U. S. 59 r (I929).

6r. Uniform Printing \& Supply Co. v. Commissioner, 88 F. (2d) 75 (C. C. A. 7th, 1937), 37 CoL. L. REv. 872; 50 HARV. L. REv. 132I.

62. Uniform Printing \& Supply Co. v. Commissioner, 88 F. (2d) 75, 76 (C. C. A. 7th, I937).

63. Uniform Printing \& Supply Co. v. Commissioner, 88 F. (2d) 75 (C. C. A. 7th, 1937); State v. Morgan Gin Co., I86 Miss. 66, 189 So. 817 (1939); cf. Gallatin Farmers Co. v. Shannon, I09 Mont. I55, 93 P. (2d) 953 (1939). Probably the most thorough discussion of the problem appears in the majority and minority opinions of the members of the House of Lords in New York Life Insurance Co. v. Styles, I4 App. Cas. $38 \mathrm{r}$ (1889). 9 th, I940).

64. Cooperative Oil Ass'n, Inc. v. Commissioner, II5 F. (2d) 666, 669 (C. C. A. 
operations have produced excess receipts. ${ }^{65}$ It is important, therefore, that cooperatives which are incorporated under statutes applicable to ordinary business corporations should provide in their articles of incorporation and by-laws that any distribution of excess receipts will be by way of patronage refunds.

Patronage refunds could be handled in two ways. In most of the reported cases it seems that they have been treated as a deduction from gross income to arrive at net income. Thus in Fruit Growers' Supply Co. v. Commissioner, ${ }^{66}$ there was deducted from gross income the sum of $\$ 1,3$ I 2, I I 4.21 leaving a net income of $\$ 42$ I, I38.87. The same result in the case of a consumers' or business purchasing cooperative could be reached by deducting the patronage refunds from gross receipts or from the selling price in order to arrive at gross income. This latter method seems to be more in accord with the facts. Thus, if $A$ sells ro radios for $\$$ Ioo subject to a five per cent. discount, his gross income is $\$ 950$. Likewise, if he charges $\$ 100$ per radio and agrees to rebate $\$ 50$ on the sale of the tenth radio, his gross income after the sale of the tenth radio is $\$ 950$. Similarly, if the cooperative collects $\$ 1000$ for ten radios and distributes a patronage refund thereon of $\$ 50$, its gross income should be considered to be $\$ 950$. True, the amount of the patronage refund was not specifically fixed at the outset, but it was understood because of the nature of a cooperative organization ${ }^{67}$ that so much of the money as was not needed would be returned.

Patronage refunds are often labelled dividends but that manifestly does not make them dividends within the meaning of the Internal Revenue Code. ${ }^{68}$ The same point has been made recently with regard to the determination of whether a cooperative could deduct six per cent. paid on so-called certificates of deposit. ${ }^{69}$ The court, holding immaterial the nomenclature used by the parties, ${ }^{70}$ concluded that under the

65. Peoples Gin Co., Inc. v. Commissioner, II8 F. (2d) 72 (C. C. A. 5th, 194I); cf. Fruit Growers' Supply Co. v. Commissioner, 56 F. (2d) 90 (C. C. A. 9th, I932). In fact in England it has been held that a non-cooperative corporation is subject to a tax on its entire income even though it distributes to its patrons a portion of that income pursuant to a prior specific agreement with reference thereto. Last v. London Assurance Corp., ro App. Cas. 438 (r885) ; cf. Sunset Scavenger Co. v. Commissioner, 84 F. (2d) 453 (C. C. A. 9th, 1936), where the court held that there was no evidence of an agreement to turn over all the profits. But cf. Central Life Assur. Soc. Mut. v. Commissioner, 5I F. (2d) 939 (C. C. A. 8th, I93I).

66. 56 F. (2d) 90 (C. C. A. 9 th, 1932). But cf. State v. Morgan Gin Co., 186 Miss. 66, 189 So. 817 (I939).

67. In Jewelers' Safety Fund Society v. Lowe, 274 Fed. 93 (C. C. A. 2d, 192I), however, a distinction is made between the payment of a regular premium to a cooperative and a deposit to cover estimated losses and expenses.

68. Uniform Printing \& Supply Co. v. Commissioner, $88 \mathrm{~F}$. (2d) 75 (C. C. A. 7 th, I937); see Baltimore Equitable Soc. v. United States, 3 F. Supp. 427, 43 I (Ct. Cl. I933), cert. denied, 290 U. S. 662 (I933). r94I).

69. Bakers' Mutual Coop. Ass'n v. Commissioner, II7 F. (2d) 27 (C. C. A. 3d,

70. See New York Iife Insurance Co. v. Styles, I4 App. Cas. 38I, 409 (I889) (reference by cooperative to its receipts as profits does not make them profits). 
facts peculiar to that case the six per cent. was not interest on a loan but rather a dividend on capital investment. ${ }^{71}$

\section{Taxability of Receipts Retained in Reserves oR Surplus}

Several recent decisions seem to cast doubt upon a earlier statement of the writer that: "Even if the cooperative accumulates such excesses and does not refund them to members, there appears nonetheless to be no taxable income, but rather a surplus either contributed by the members or a surplus in which they retain a specific interest." 72 A significant case supporting this proposition is the decision of the House of Lords in Jones $v$. Southwest Lancashire Coal Oweners' $A s^{\prime} n{ }^{73}$ where an unsuccessful attempt was made to distin ${ }^{m i s h}$ an earlier case on the ground that excess receipts were "carried to reserve and not at once returned to members" in the form of patronage refunds. It was there said:

"Sooner or later, in meal or in malt, the whole of the company's receipts must go back to the policyholders as a class, though not precisely in the proportions in which they have contributed to them; and the association does not in any true sense make a profit out of their contributions." 74

An important fact about the recent cases, which on their face appear to cast doubt upon the correctness of this proposition, is that in each of them the cooperative dealt with non-members. This is significant for two reasons. First, the issue in most of these cases was only that of tax exemption which was denied because of inequality in treatment of non-members. ${ }^{75}$ Accumulations of surplus were referred to in those cases to show the lack of equality between members and nonmembers, which results in a denial of the exemption, but no disposition is made of the question as to the extent to which those accumulations are taxable.

Second, the dealing with non-members is important, because the accumulations of reserves or a surplus at the expense of non-members

7x. Cf. Farmers Union Coop. Co. v. Commissioner, 90 F. (2d) 488 (C. C. A. 8th, 1937); South Carolina Produce Ass'n v. Commissioner, $50 \mathrm{~F}$ (2d) 742 (C. C. A. 4th, I93I) ; Gallatin Farmers Co. v. Shannon, I09 Mont. I55, 93 P. (2d) 953 (I939). But cf. Garden Homes Co. v. Commissioner, 64 F. (2d) 593 (C. C. A. 7th, I933).

72. Packer, Cooperatives (r940) I9I. The possible effect of the recent cases was pointed out in Hulbert, Book Review (I94I) 89 U. of PA. L. REv. III6, III7.

73. [1927] A. C. 827 .

74. Id. at 832 .

75. Fertile Cooperative Dairy Ass'n v. Huston, IIg F. (2d) 274 (C. C. A. 8th, I94I), aff'g 33 F. Supp. 712 (N. D. Iowa, I940) ; Farmers Union Coop. Co. v. Commissioner, 90 F. (2d) 488 (C. C. A. 8th, 1937); Farmers Union Coop. Supply Co. v. United States, 25 F. Supp. 93 (Ct. Cl. I938); Farmers Coop. Co. v. United States, 23 F. Supp. I23 (Ct. Cl. I938); Farmers Union Coop. Supply Co. v. United States, 23 F. Supp. I28 (Ct. CI. I938). 
can result in corporate profits; and, therefore, under such circumstances patronage refunds or capital accumulations do not represent mere excess charges made against members. In one of these cases, however, the court went very far in its language. ${ }^{76}$ It took the viewpoint that a "Reserve for Working Capital" could not be deducted because the statute does not authorize such a deduction. The failure to allocate to non-members an interest in such a reserve appears to justify the decision. ${ }^{77}$ Yet, the opinion as it stands ignores the fundamental principle that payments by members of a cooperative are made to meet the requirements of the cooperative. If the members choose to raise reserves by imposing assessments, by requiring larger payments from members, or by withholding patronage refunds, the result is the same as far as the excess is concerned; it is not taxable income.

It has already been indicated that the payments by members are not intended to produce any entrepreneur profit. It matters not, therefore, whether part of those payments are returned as patronage refunds or are retained for capital purposes. Thus in Garden Homes Co. v. Commissioner ${ }^{78}$ the court said with regard to excess receipts not distributed by way of patronage refunds but credited to the capital account of the members:

"Hence they are to be considered as capital contributions and not as profit to petitioner within the meaning of the statute. A corporation cannot receive profits from the sale of its common stock sold at par, or by reason of the receipt of capital contributions from its stockholders." 79

A fair deduction from the foregoing authorities, therefore, is that excess receipts from members whether used for patronage refunds or for capital accumulations do not constitute income within the normal meaning of that word.

\section{CONCLUSION}

Cooperatives are neither tax dodgers nor tax evaders. They are quick, however, to resent discriminatory treatment. They have considered it part of their liberty and freedom of action to avoid unnecessary governmental regulation. They consider it part of that same liberty and freedom to avoid taxation not applicable to them. 1940).

76. Cooperative Oil Ass'n, Inc. v. Commissioner, II5 F. (2d) 666 (C. C. A. 9th,

77. An allocation of interests in such a reserve was the basis for holding the cooperative free from liability in Midland Coop. Wholesale, 44 B. T. A. 824 (I94I).

78. 64 F. (2d) 593 (C. C. A. 7th, 1933) ; accord: Cambridge Apt. Bldg. Corp., 44 B. T. A. 6I7 (I94I) ; 874 Park Avenue, 23 B. T. A. 400 (I93I). Compare the cases holding that no income is realized from the forfeiture of stock subscriptions. Commissioner v. Inland Finance Co., 63 F. (2d) 886 (C. C. A. 9th, I933); Realty Bond \& Mortgage Co. v. United Sitates, r6 F. Supp. 77I (Ct. Cl. 1936).

79. 64 F. (2d) 593,598 (C. C.. A. 7th, 1933). 
The time is ripe for Congressional examination of the income tax status of cooperatives. There should be clarification of the applicability of the income tax laws to the receipts of cooperatives. There is no reason why interest, dividends, rents and other income received by cooperatives should not be subject to the income tax. With reference to such earnings, there is no distinction between a cooperative enterprise and an ordinary business enterprise. ${ }^{80}$ Of course, if Congress desires to foster the growth of cooperatives in a particular field or in all fields, it can grant them exemption from any and all taxes. That question, however, does not call for legal analysis. It is for the people to decide through their representatives whether the economic democracy of cooperatives is so desirable that it should be fostered to the same extent as other exempt institutions.

In contrast to capital earnings of cooperatives are their receipts from members. A tax on those receipts or on the unspent portion of those receipts is no more an income tax than is the tax on club dues. It might well be that cooperatives may grow to such an extent that the elimination of ordinary business enterprise will curtail income taxes, but when that time comes the problem can be met with appropriate legislation. To tax cooperatives on their patronage refunds or on their reserves or surplus is wholly unsatisfactory, because the tax could so easily be avoided. To take the illustration referred to in the early part of this article, the cooperative could require additional capital investment by its members and then could charge five-sixths of the market price for gasoline so that at the end of the year it would have no taxable income. The illustration makes clear that cooperatives do not make "profits" as a result of dealings with their own members.

The future is vibrant with economic change. Whether or not cooperatives will play a major role in a new order, time alone will tell. Yet, the economic democracy of cooperatives and their mode of operation call for the immediate consideration of their income tax problems on a sound logical basis rather than on the future emotional outpourings of their biased protagonists or antagonists. ${ }^{81}$

80. "The fact that the investment resulting in accumulation or dividend is made by a cooperative as distinguished from a capitalistic concern does not prevent the amount thereof being properly deemed a profit on the investment." Brandeis, $J$, in Penn Mutual Life Ins. Co. v. Lederer, 252 U. S. 523, 534 (I920).

8I. After this article was in galley proof in the hands of the printer, the writer learned of the article by Joseph O'Meara, Jr., entitled The Federal Income Tax in Relation to Consumer Cooperatives (194I) 36 ILL. L. REv. 60. That article, inter alia, stresses the immateriality from the income tax standpoint, of the incorporation of consumers' cooperatives and concludes: "The taxation of consumer cooperative associations has proceeded on an erroneous assumption deriving from Eisner $v$. $M a-$ comber. Contrary to that assumption, so long as these non-profit mutual-benefit undertakings confine themselves to their proper functions they have no income [i. e., from operations] under the Sixteenth Amendment and cannot validly be required to pay an income tax." 